\title{
Phase locking and resetting in human subthalamic neurons
}

\author{
Shuoguo Wang ${ }^{*}$, Ted Weyand, Erich Richter, Carmen C Canavier \\ From Twentieth Annual Computational Neuroscience Meeting: CNS*2011 \\ Stockholm, Sweden. 23-28 July 2011
}

Microelectrode recordings were obtained from human subthalamic nucleus (STN) in parkinsonian patients using a "Ben gun" array of 5 microelectrodes [1] prior to implantation of a deep brain stimulation electrode, and digitized at $25 \mathrm{kHz}$. Neuronal spikes were threshold extracted ( $>4 S D$ above baseline). Single units were confirmed using a spike sorting algorithm [2]. Spike trains were then constructed at $1 \mathrm{kHz}$ with unit impulses at each spike time (Fig. 1B) and zeros elsewhere. Episodes of tremor related activity were identified in which the spectral peak in the tremor range $(2-6 \mathrm{~Hz})$ was substantially higher than baseline (Fig. 1D). Spike trains corresponding to identified oscillatory activity were then band pass filtered (2 to $6 \mathrm{~Hz}$ ) to produce a continuous signal (Fig. 1A) corresponding to the envelope of the low frequency activity [3]. The Hilbert transform was used to reconstruct the phase of this signal at each time point. The derivative of this waveform gives the instantaneous frequency (Fig. 1C), and large deviations from the baseline rate of about $4 \mathrm{~Hz}$ indicate that the phase of the oscillation has been reset. We identified spontaneous phase advances (Fig. 1A1,B1, and C1) in which the next burst occurred sooner than expected as well as spontaneous phase delays (Fig. 1A2,B2, and C2)in which the

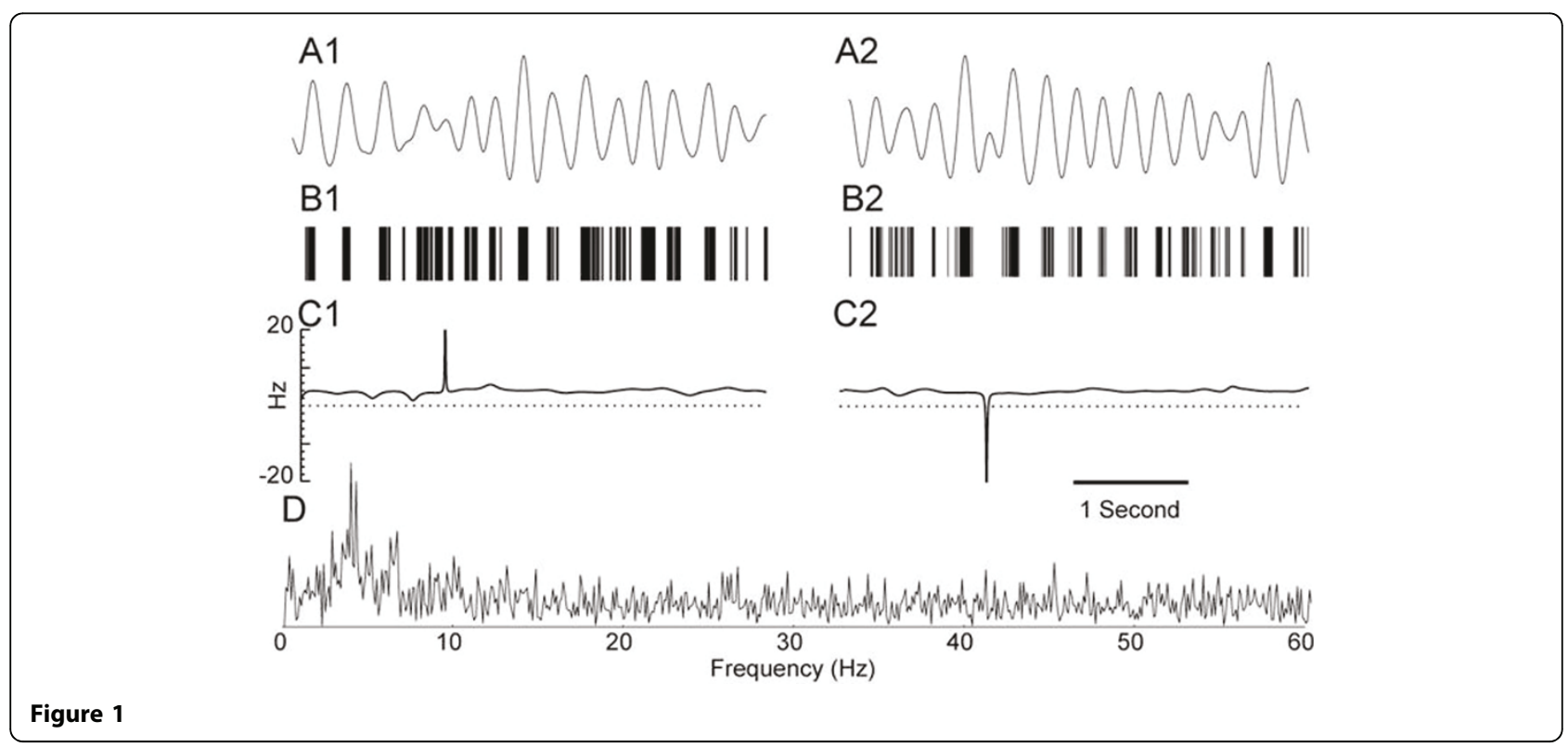

Neuroscience Center of Excellence, LSUHSC, New Orleans, LA 70112, USA

Full list of author information is available at the end of the article

(C) 2011 Wang et al; licensee BioMed Central Ltd. This is an open access article distributed under the terms of the Creative Commons 
next burst occurred later than expected. Our goal is to better understand abnormal synchronization in the STN.

\section{Acknowledgements}

Supported by a translational research supplement to R01NS054281 under

the CRCNS program.

Published: 18 July 2011

\section{References}

1. Benabid AL, Pollak P, Louveau A, Henry S, de Rougement J: Combined (thalamotomy and stimulation) steroetactic surgery of the VIM thalamic nucleus for bilateral Parkinson's disease. Appl. Neurophysiol 1987, 50:344-6.

2. Quiroga $R Q$, Nadasdy Z, Ben-Shaul Y: Unsupervised spike detection and sorting with wavelets and superparamagnetic clustering. Neural Comput 2004, 16(8):1661-87.

3. Hurtado JM, Rubchinsky LL, Sigvardt KA: Statistical method for detection of phase-locking episodes in neural oscillations. J Neurophysiol 2004, 91:1883-1898.

doi:10.1186/1471-2202-12-S1-P28

Cite this article as: Wang et al:: Phase locking and resetting in human subthalamic neurons. BMC Neuroscience 2011 12(Suppl 1):P28.

Submit your next manuscript to BioMed Central and take full advantage of:

- Convenient online submission

- Thorough peer review

- No space constraints or color figure charges

- Immediate publication on acceptance

- Inclusion in PubMed, CAS, Scopus and Google Scholar

- Research which is freely available for redistribution

Submit your manuscript at www.biomedcentral.com/submit 